\title{
Article 27. Subsidiary Bodies
}

1. Any subsidiary body established by or under the Convention may serve this Protocol, including upon a decision of the Conference of the Parties serving as the meeting of the Parties to this Protocol. Any such decision shall specify the tasks to be undertaken.

2. Parties to the Convention that are not Parties to this Protocol may participate as observers in the proceedings of any meeting of any such subsidiary bodies. When a subsidiary body of the Convention serves as a subsidiary body to this Protocol, decisions under this Protocol shall be taken only by Parties to this Protocol.

3. When a subsidiary body of the Convention exercises its functions with regard to matters concerning this Protocol, any member of the bureau of that subsidiary body representing a Party to the Convention but, at that time, not a Party to this Protocol, shall be substituted by a member to be elected by and from among the Parties to this Protocol.

Article 27 establishes the institutional and procedural linkages between the Protocol and the свD. It addresses: the performance of functions by subsidiary bodies of the CBD in relation to the Protocol; which States are entitled to participate in the proceedings of subsidiary bodies performing functions in relation to the Protocol; and who is entitled to act as an officer (or 'bureau member') of such a subsidiary body. ${ }^{1}$

This provision is modeled after the Biosafety Protocol, ${ }^{2}$ with the only difference concerning the link between the CBD COP and the Protocol COP/MOP. Notably, the Nagoya Protocol foresees the possibility that CBD subsidiary bodies will support the work of the Nagoya Protocol COP/MOP without the need for a decision to this end to be taken by the COP/MOР. ${ }^{3}$ Thus, CBD subsidiary bodies, such as the Working Group on Review of Implementation, the Working

1 Greiber et al., Explanatory Guide, op. cit., 236-237. For a similar discussion in relation to the Biosafety Protocol, see Mackenzie et al., Explanatory Guide to the Cartagena Protocol, op. cit., 185-186.

2 Biosafety Protocol Article 30.

3 Note the word 'including' in Nagoya Protocol Article 27(1). The Biosafety Protocol, instead, requires such decision by its own COP/MOP. 
Group on Article $8(\mathrm{j})$ on traditional knowledge ${ }^{4}$ or the CBD Subsidiary Body on Scientific, Technical and Technological Advice (sbstTA), could - upon a request by the $\mathrm{CBD}$ СОР - address issues related to the implementation of the Protocol. In practice, however, it seems rather likely that specific instructions will be provided by the COP/MOP to that end. In this connection, it can be argued that if tasks related to the Nagoya Protocol would significantly add to the workload or costs of certain CBD subsidiary bodies, the CBD COP could exercise its right to 'consider and take any additional action that may be required for the achievement of the purposes of this Convention' to intervene in this event. ${ }^{5}$

Following the approach taken with regard to the COP/MOP, representatives of non-Parties to the Protocol could only participate as observers when a subsidiary body of the СвD exercises functions in relation to the Protocol. Note also that the CBD Rules of Procedure apply, as appropriate, to its subsidiary bodies, and that when a CBD subsidiary body carries out functions under the Protocol, any member of the bureau who does not represent a Party to the Protocol must be replaced by a representative of a Party to the Protocol. ${ }^{6}$

4 In the context of which, in effect, consideration of guidelines on prior informed consent to, prevention of misappropriation of, and benefit-sharing from traditional knowledge are being considered with a view to contributing to the work of the Nagoya Protocol. See свр Article 8(j) Working Group, "Report of the eighth meeting," UneP/CвD/COP/12/5, Annex, 'Recommendation 8/4 on Tasks 7, 10 and 12 could best contribute to work under the Convention and to the Nagoya Protocol.

5 Свр Article 23(4)(i), on the basis of similar considerations made in relation to the Biosafety Protocol. See Mackenzie et al., Explanatory Guide to the Cartagena Protocol, op. cit., 185. See also Glowka, Burhenne-Guilmin and Synge, Guide to the Convention on Biological Diversity, op. cit., 112.

6 Greiber et al., Explanatory Guide, op. cit., 237. For a similar discussion in relation to the Biosafety Protocol, see Mackenzie et al., Explanatory Guide to the Cartagena Protocol, op. cit., 186. 